\title{
Industrial Principles Applied in the Shops of the American Sash and Door Company
}

\author{
KANSAS CITY, MISSOURI
}

\author{
By F. J. Moss \\ President
}

I

SHALL state only the fundamental principles which I believe to be basically sound because, assuming that the wages or salaries paid in each individual case are in keeping with the worker's worth to the business, the returns to him under this plan are in the exact proportion that he contributes to the success of the business. I state "returns" to the worker, which, of course, include wages and his share of the profits.

In arriving at returns to labor and capital under my plan, the purpose has been to determine what in fact is the correct return, rather than to state what in my opinion, or the opinion of any other person, might be the correct return. In order to do this I have dealt with only two factors of cost, viz., labor and capital, which is correct, because in the last analysis, regardless of the number of divisions and subdivisions in cost accounting, there are but two factors of cost-labor and capital.

Applying this rule, the following principles are what $I$ am contending for, and putting into operation as far as possible in the absence of this or some other plan being generally adopted.

\section{Returns to Labor and Capital}

The product of labor today, if conserved, is capital tomorrow; and because a worker has not the capital to invest in the business in which he is employed, or possibly is not permitted to invest, is no justification for depriving him of the profit on that part of the capital he provides, which is represented in the wages received. That is to say, if the actual vested capital in a business undertaking is $\$ 800,000$ and the payroll (including salaries and wages of every nature) is $\$ 200,000$ per annum, then labor has furnished onefifth of the capital, and should receive one-fifth of the profits made during the year, after paying a fair rate of interest upon the vested capital. Thus the returns to labor and capital in the business is in the exact proportion to the contributions of each.

\section{Organized and Unorganized Labor}

It is generally admitted that organized labor, operating under union rules and restrictions, is far less efficient than in the case of unorganized labor. Therefore, it is the height of ingratitude and stupidity to pay a lesser wage to the loyal non-union man than is paid to the organized group of workers in the same industry, as it has the effect of forcing other workers in self-protection to organize or join the union contrary to their wishes.

The crying need in all lines of business is more production, and yet every influence at Washington has encouraged shorter hours, even during the war when patriotism should have inspired every man to his maximum production. Our people have been led to believe that they can work fewer hours and enjoy the same comforts if the wage rate per hour is increased. We must get back to sound principles and encourage industry and thrift. 
In addition to paying unorganized labor the same wage as organized labor, good morals demand that we recognize what every student of cost should know, and that is that the longer work hours effect a saving to the manufacturer in the overhead expense; that is to say, the 9-hour work day effects a saving of approximately 10 per cent on the overhead burden as against an 8-hour work day. Plain justice demands that the saving thus effected should go to the worker because it not only effects a saving in production cost, but also increases the output and sales upon which the additional profit can be realized. The invariable and universal rule should be that if the wage scale for.an 8-hour day is 70 cents per hour, the 9-hour-perday worker should receive 77 cents per hour, and the 10-hour-per-day worker should be rewarded on the basis of 84 cents per hour.

In indicating the wage rate per hour and saving effected, it is for the purpose of illustration only, the principle being that the saving in the production cost, by reason of a longer work day, should go to the worker. Until this principle shall have been generally recognized and made a part of our industrial system, we will suffer from industrial paralysis. We cannot have industrial harmony in the absence of justice both to employer and employee. With justice will come efficiency, increased production, and increased earning and consuming capacity.

\section{Fair Business Principles}

It is futile for us to close our eyes to the fact that it is human to be selfish. That being the case, it should not be left to any one man or group of men to demand or exact the enforcement of their will at the sacrifice of good morals. Some of our captains of industry advocate as a principle to deal liberally with labor, and yet we know there is no question upon which men differ more than upon the question of liberality; all of which argues in favor of establishing a uniform basis or set of principles that are admittedly fair to all concerned.

The establishment of these principles should engage our best thought. To this end I suggest that within each industry a committee or commission be established consisting of three or five members, more or less, as may be necessary, to be chosen by the industry and to be composed of trained experts, none of which shall be interested in the business as such, so that they may be without prejudice, and at the same time familiar with the problems of the industry. This committee shall keep on file constantly the wage scale in effect at every plant in the industry. These records are to be available to anyone upon request. At the request of an employer or signed petition by the majority of the employees in any one individual business, calling for an investigation bearing upon the question of wages or work conditions, such investigation shall be made, and at least a part of the expense is to be borne by the parties making the request. The report of the findings shall be filed-a copy with the employer, a copy with the employees and another copy with the public press.

What $I$ have in mind is the allpotent factor of public opinion. When properly informed public opinion will invariably be found on the side of good morals, and under a plan such as suggested, an appeal to the board for investigation would not be made except in cases where injustice was being worked; and no employer or group of employees can stand against right and the power of public opinion.

I have outlined only the outstanding principles which are based on good 
morals and sound economics. When labor is assured that it will take out of the business all of the profit on all that labor contributes to such business, and when this rule has become generally established, there will be no cause for radical labor leadership, nor likelihood of labor unrest nor discontent.

We must approach this subject with a thorough understanding and admission that selfishness on the part of a few employers is largely responsible for the present feeling of discontent. Moreover, it is clearly our duty to take such steps as may be necessary to cure these evils within our own ranks, at the same time being in position to resist any unjust demands that may be made, growing out of an organized group of men seeking to enforce their will, regardless of whether it is right or wrong, and regardless of the hardship that it might work to their employer or the industry. 